\title{
THE DIMENSIONALITY ON THE MAYOR OF SURAKARTA'S (2016-2021) JAVANESE COVID-19 POSTERS
}

\author{
Hanif Burhanudin ${ }^{1 *}$; Sumarlam²; Ani Rakhmawati \\ ${ }^{1-3}$ Regional Language and Literature Education (Postgraduate), \\ Faculty of Teacher Training and Education, Sebelas Maret University \\ Jl. Ir. Sutami No. 36, Kentingan, Surakarta, Jawa Tengah 57126, Indonesia \\ 'burhanudinhanif@gmail.com; ${ }^{2}$ sumarlam@staff.uns.ac.id; ${ }^{3}$ anirakhmawati@staff.uns.ac.id
}

Received: $03^{\text {rd }}$ February 2021/ Revised: $23^{\text {rd }}$ March 2021/ Accepted: $30^{\text {th }}$ March 2021

How to Cite: Burhanudin, H., Sumarlam., \& Rakhmawati, A. (2021). The dimensionality on the mayor of Surakarta`s (2016-2021) Javanese COVID-19 posters. Humaniora, 12(2), 161-171. https://doi.org/10.21512/humaniora.v12i2.7009

\begin{abstract}
The research aimed to describe dimensions of the Mayor of Surakarta's (2016-2021) Javanese COVID-19 posters. The research design was qualitative with Fairclough's Critical Discourse Analysis (CDA) paradigm. The research data were the two Javanese COVID-19 posters retrieved from the Mayor of Surakarta's (20162021) Instagram account. Data were analyzed in three stages: (1) Analyzing linguistically by paying attention to textual and linguistic elements, (2) Analyzing its discourse process, and (3) Analyzing by examining the sociocultural context. This research finds three dimensions: (1) textual dimension; those posters are constructed by the Javanese language with a persuasive-educative form. Also, there is a relationship between consumers and producers that are interwoven in power and cultural relations. (2) Discourse practice dimension, the process of production, distribution, and consumption, shows that the poster is produced and distributed directly by the ruling institution through social media and is intended to be consumed by Surakarta's citizens. Also, there are intertextual refers to the central government regulations. (3) Socio-cultural dimension, three levels are found. Those three levels are the situational, institutional, and social levels, which show that the poster is influenced by pandemic situations and contexts beyond the language, such as Surakarta's cultural context and social conditions. Based on these dimensionalities, the poster is functioned by the Mayor of Surakarta's Institution to persuade, educate, and influence the citizen, also to respond to the COVID-19 situation.
\end{abstract}

Keywords: socio-linguistic, critical discourse analysis, language power, COVID-19 poster

\section{INTRODUCTION}

The COVID-19 pandemic poses critical challenges for public health and research (Fauci, Lane, \& Redfield, 2020). In December 2019, the coronavirus (SARS-CoV-2) was first discovered in Wuhan City, Hubei Province, then spread throughout China (Mo et al., 2020). Ultimately, in early 2020 the COVID-19 spread around the world, infecting millions of people and causing problems on an unprecedented scale (Olivia, Gibson, \& Nasrudin, 2020). On March 11, 2020, WHO declared the COVID-19 outbreak as a global pandemic (Mahase in Radi et al., 2020).
Indonesia is one of the countries affected by the COVID-19. The Indonesian government issues various policies to minimize the spread of the virus, such as social distancing, physical distancing, largescale social distancing, work from home, and learning from home (Damayamti \& Masitoh, 2020). The central government and local governments continue to strive to deal with the pandemic, including the Mayor of Surakarta (2016-2021), F. X. Hadi Rudyatmo. The mayor of Surakarta tries to overcome the COVID-19 pandemic with various efforts, one of which is persuasion efforts through posters. After all, persuasion efforts through persuasive and educational 
posters are crucial to do for the sake of increasing public awareness in dealing with the COVID-19 pandemic (Bechler \& Tormala, 2020; Yuvaraj, 2020).

Through his Instagram account, F. X. Hadi Rudyatmo releases persuasive-educative posters about WFH and health protocols to the public. Instead of using the Indonesian language, those posters are compiled in the Javanese language. Those posters are interesting to research because the poster is part of the discourse phenomenon that emerges amid the COVID-19 pandemic. The COVID-19 has implications for various fields of life, causing interest among researchers from various disciplines, one of which is language research (Sultan \& Rapi, 2020). Based on this, the researcher is interested in examining the poster released by the Mayor of Surakarta.

As a discourse, those Javanese COVID-19 posters are closely related to the dimensionality aspect. It means those posters are not just texts, but there is a dimensional layer that constructs those posters. By revealing these dimensions, the essence of the dimensionality and various contexts that exist behind the discourse will be known. So the research aims to uncover and describe the dimensions contained on the Mayor of Surakarta's Javanese COVID-19 poster.

The research uses Norman Fairclough's Critical Discourse Analysis (CDA) approach to uncover and describe that dimensionality problem. Fairclough argues that every discursive event is not just a text, but in every discourse exists three dimensions. Those three dimensions are dimensions of the text, discursive practice, and sociocultural practice (Fairclough, 2010). Therefore, Norman Fairclough's CDA is called the three-dimensional model. This Faircough framework can be described in Figure 1.

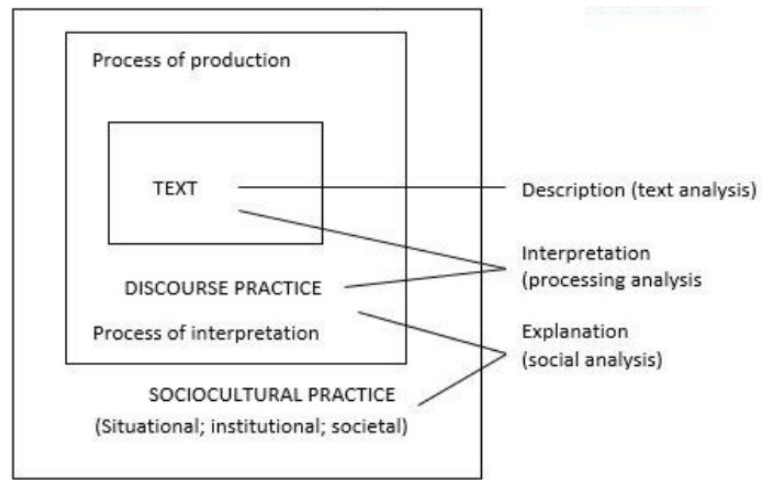

Figure 1 CDA Three Dimensional Norman Fairclough (Fairclough, 2010)

Based on Figure 1, the Fairclough 's CDA model consists of three dimensions of analysis. Those three dimensions are the text dimension, the discursive practices dimension, and the sociocultural practices dimension. Then Fairclough (2010) divides these dimensions into various aspects. Text dimensions are related to linguistic elements, relations, identity, and representation; discursive practice dimensions relate to text production, distribution, and consumption. The sociocultural practice dimension is related to the analysis of macro contexts. The sociocultural dimension is divided into three levels. Those three levels are situational, institutional, and social (Fairclough, 2010; Eriyanto in Lubis, 2020). CDA is an interdisciplinary science with the scope of sociology, politics, linguistics, and others (Fariclough 2010). Therefore CDA studies sometimes have diverse topics.

Several previous discourse studies have relevance to the research. Azizan, Ismail, and Qaiwer's (2020) research has examined the effect of 15 positive discourses on social media on Malaysian society during the implementation of the MCO (Movement Control Order) amid the COVID-19 pandemic. Azizan, Ismail, \& Qaiwer (2020) use Norman Fairclough's CDA model to study the problems. Sultan and Rapi's research (2020) has discussed discursive strategies carried out by government representatives amid COVID-19. This research uses a Positive Discourse Analysis (PDA) approach. Then the research is conducted by Tiruneh, Baye, and Dubi (2020). Tiruneh's research aims to analyze various discourses on social media related to the COVID-19 pandemic in Ethiopia. Furthermore, there is research by Suprayitno (2020) which examines the discourse construction of Joko Widodo's leadership representation in handling COVID-19 on the Indonesian CNBC infographic. Suprayitno's research uses the CDA Norman Fairclough framework approach. Based on these studies, there is relevancy with the research; those research and the research are both discussing the phenomenon of language and discourse that emerged amid the COVID-19 pandemic and its relation to the latest information technology (social media, internet, network systems, and others).

There are several differences or gaps with previous research; first, the research investigates the discourse of posters produced by the mayor of Surakarta (2016-2021) as Javanese discourse that has rarely been studied before. So far, it is rare to find critical discourse studies that discuss Javanese discourse (especially posters) related to the context of the COVID-19 situation. However, recent research by Burhanudin, Sumarlam, and Rakhmawati (2021) uses a critical discourse analysis approach to discuss the Javanese posters related to the handling of COVID-19. Second, the poster uses Javanese, so the research also plays a role in examining the phenomenon of regional language discourse that emerged during the COVID-19 pandemic. This also tries to dissect the dimensionality elements of Javanese language posters by using the Fairclough's CDA approach.

The research also shows that not only national or international discourse, the powerholders (leaders) also use the richness of regional languages to produce discourses in dealing with COVID-19. However, this kind of discourse is scarce. As a discourse, those Javanese COVID-19 posters are closely related to the dimensionality aspect. By revealing these dimensions, the essence of the dimensionality and various contexts 
that exist behind the discourse will be known. So the research aims to uncover and describe the dimensions using Fairclough's CDA dimensional framework. The research is also a form of concern for local languages, which are increasingly deteriorating amid this disruption era.

\section{METHODS}

The research design is a qualitative research with the perspective of Norman Fairclough's threedimensional CDA framework. The Fairclough's CDA perspective observes language not only traditionally (micro linguistics) but also at a macro or broader context and also observes the relationship between discourse and social structures (Saraswati \& Sartini, 2017). Then in applying his discourse analysis, Fairclough divides the reality of discourse into three dimensions: text, discourse practice, and sociocultural. The qualitative design with the Fairclough `s CDA paradigm is used to reveal the dimensionality of the mayor of Surakarta's (2016-2021) Javanese COVID-19 posters.

The data are two Javanese COVID-19 posters from the Mayor of Surakarta (F. X. Hadi Rudyatmo), who served from 2016 to 2021. Those two posters are obtained from F. X. Hadi Rudyatmo's official Instagram account. The first poster was uploaded on March 28, 2020, and the second was uploaded on April 8, 2020. The collecting data method is the literature study method. The research data looks minimal, but that is the whole data. Researchers have observed on the internet, site, or social media, especially on the Mayor of Surakarta's (2016-2021) account. The researchers have found that the Mayor of Surakarta (2016-2021) only released two full Javanese posters until the end of office in February 2021. Moreover, those two posters are related to COVID-19. From a certain perspective, this can also be seen as uniqueness. The context of the COVID-19 situation has led to the emergence of these two Javanese language posters, whereas previously, the Surakarta major's agency had never released a full Javanese language poster. Furthermore, this uniqueness is one of the attractions for studying those posters.

The data analysis method uses Norman Fairclough's three-dimensional CDA. Based on Fairclough in Sumarlam (2016) and Eriyanto in Lubis (2020), those COVID-19 posters will be analyzed in three stages. The first stage is the textual dimension analysis (description). At this stage, the poster's language aspects, such as language use, grammar, sentence form, and vocabulary are analyzed. The second stage is discourse practice analysis; at this stage, the researchers analyzes and interpret the posters by relating them to the production, distribution, and consumption processes. Also, at this stage, the intertextual aspects of the text are analyzed. The third stage is the analysis of the sociocultural dimension. In this stage, the researchers link the discourse production with attention to the macro contexts outside the text, such as social context, culture, phenomena, events, and others. This third stage are divided into three levels. Those three levels are situational, institutional, and social levels. On the situational level, it discusses the unique situation that influenced the emergence of those posters. On the institutional level, it analyzes the influence of institutions on the production process of those posters. The social level deals with the macro contexts such as social conditions, economic systems, politics, or culture.

\section{RESULTS AND DISCUSSIONS}

The first dimension is the textual dimension that leads to textual analysis from the linguistic perspective. Norman Fairclough also calls this dimension a descriptive process (Fairclough in Sumarlam, 2016). On this dimension, each poster is analyzed and described for its language and textual elements without paying much attention to the context outside the language. Before moving to the textual analysis, at this stage, it will present the posters, transcripts, and transliterations of the text. Figure 2 shows the poster of appeal to prevent COVID-19.

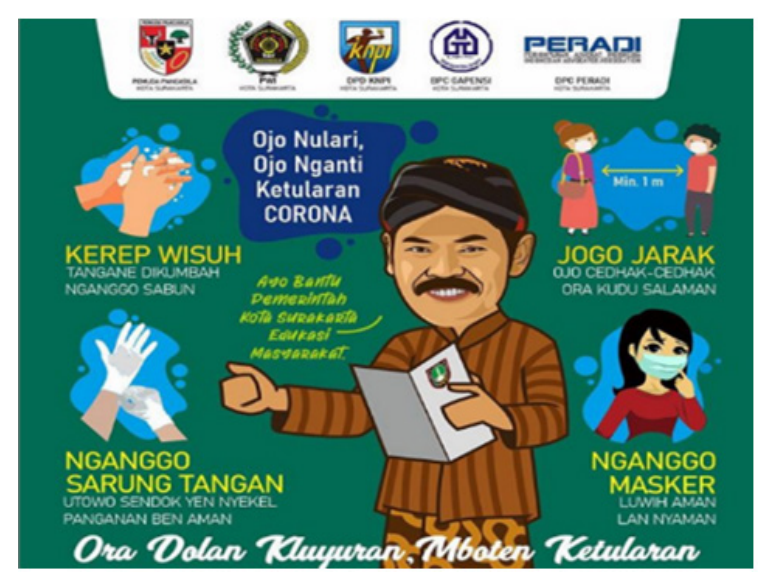

Figure 2 Poster of Appeal to Prevent COVID-19 (Rudyatmo, 2020)

$\begin{array}{lll}\text { Text: } & \text { Ojo Nulari, Ojo Nganti Ketularan } \\ & \text { CORONA. } \\ \text { 2) } & \text { Ayo Bantu Pemerintah Surakarta } \\ & \text { Edukasi Masyarakat. } \\ \text { 3) } & \text { NGANGGO SARUNG TANGAN, } \\ & \text { UTOWO SENDOK YEN NYEKEL } \\ & \text { PANGANAN BEN AMAN } \\ \text { 4) } & \text { KEREP WISUH, TANGANE } \\ & \text { DIKUMBAH NGANGGO SABUN } \\ \text { 5) } & \text { JOGO JARAK, OJO CEDHAK- } \\ & \text { CEDHAK } \\ \text { 6) } & \text { NGANGGO MASKER, LUWIH } \\ & \text { AMAN LAN NYAMAN } \\ \text { 7) } & \text { Ora Dolan Kluyuran, Moboten } \\ & \text { Ketularan }\end{array}$


Translation: 1) Don't infect, don't get infected by Corona

2) Let's help Surakarta government educate the community

3) Wear gloves, or a spoon when handling food to be safe

4) Wash your hands frequently, wash your hands with soap

5) Keep your distance, don't come close

6) Wear a mask, it is safer and more comfortable

7) Not hanging around, not infected

This poster (Figure 2) has a random topology. The reader can start reading from any direction. However, the researchers read from the middle this time, then rotated it clockwise and backed down. Textually, the poster consists of two types of sentences, namely imperative and declarative sentences. Sentences 1 and 5 are imperative of prohibition, and sentence 2 is imperative of invitation sentence. In sentence 1 , there is a repetition of the word ojo (do not), while in sentence 5 , there is also the word ojo (do not). Those words indicate an emphasis on prohibiting the reader from experiencing or doing a specific activity. In the context of that poster, the word prohibition refers to the act of nulari (infect) and the condition of ketularan (infected). This means that people are advised not to do activities that can cause infection and worsen the spreading of COVID-19.

Meanwhile, sentence 2 is the imperative sentence for persuasion because there is the word ayo (let's). The persuasion in sentence 2 refers to the request from Surakarta's mayor to the citizen to help educate others about 'methods' to prevent COVID-19 infection. Those 'methods' exist in the sentences of 3 , $4,5,6$, and 7 .

Sentences 3, 4, 6, and 7 are declarativepersuasive sentences. Declarative sentences function to convey factual information or statements to readers (Adiantika, 2020). However, in sentence 5, even though it is in the form of an imperative sentence actually, sentence 5 also provides information. The information provided by these five sentences is in the form of educational value related to actions that can prevent someone from getting infected by COVID-19. In this regard, sentences $3,4,5,6$, and 7 are the main part that contains an appeal and 'methods' to deal with COVID-19. That 'method' is the discipline of wearing protective gloves, washing hands, social distance, wearing a mask, and not wandering around. It appears that the poster is not only about a ban and persuasion but also provides educative information about the 'methods' or appropriate preventive action when dealing with the pandemic conditions.

At the language level, the poster uses two levels of language. In sentence 7 , the clause mboten ketularan (not infected) in the krama language shows politeness. While other sentences use ngoko, which brings familiar and closeness nuances.

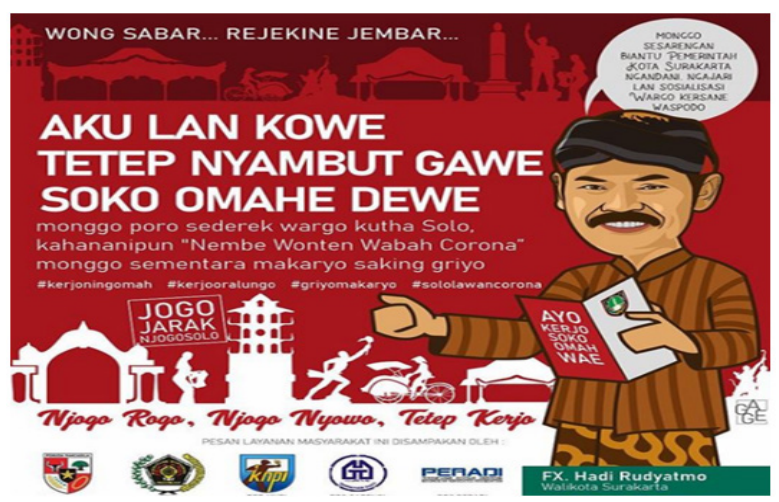

Figure 3 Poster Appeal to Work From Home (Rudyatmo, 2020)

Text:

1) $W O N G$

SABAR....REJEKINE $J E M B A R \ldots$.

2) MONGGO SESARENGAN BANTU PEMERINTAH KOTA SURKARTA

NGANDANI, NGAJARI LAN SOSIALISASI WARGO KERSANE WASPODO.

3) AKULANKOWE TETEP NYAMBUT GAWE SOKO OMAHE DEWE.

4) monggo poro sederek wargo kutha Solo, kahananipun "Nembe Wonten Wabah Corona" monggo sementara makaryo saking griyo.

5) JOGO JARAK, NJOGO SOLO.

6) AYO KERJO SOKO OMAH WAE.

7) Njogo Rogo, Njogo Nyowo, Tetep Kerjo.

Translation: 1) Don't infect, don't get infected by Corona

2) Let's help Surakarta government educate the community

3) Wear gloves, or a spoon when handling food to be safe

4) Wash your hands frequently, wash your hands with soap

5) Keep your distance, don't come close

6) Wear a mask, it is safer and more comfortable

7) Not hanging around, not infected

This poster (Figure 3) begins with sentence 1, Wong sabar, rejekine jembar (patient people, has generous fortune). This sentence tries to cultivate a sense of patience because the success of the WFH (Work from Home) policy requires patience from the community to stay at home. This first sentence is a declarative sentence that has a stylistic (rhyme) element. There is a repeated consonant ' $r$ ' at the end of each clause. This is referred to as alliteration, or in Javanese literature, it is called purwakanthi guru sastra. Alliteration (purwakanthi guru sastra) adds coherence, cohesion, and aesthetic value to the text 
(Burhanudin, Sumarlam, \& Rakhmawati, 2021). This sentence also has a coherent affinity to support the following sentences.

Sentences 2, 3, 4, 6, and 7 are the main content of the poster that contains WFH's appeals. There are repetitions of the directive words monggo (let's) and ayo (let's) in sentences 2, 4, and 6. The repetition of the directive sentence is used to emphasize the imperative and persuasion effect (Burhanudin, Sumarlam, \& Rakhmawati, 2021). Sentence 7, Njogo Rogo, Njogo Nyowo, Tetep Kerjo (maintain the body, keep soul, keep working) act as the closing sentence, which is continuously composed of three clauses. The three clauses have a style such as a slogan or jargon and have assonance (repetition of vowels) 'o', or in Javanese literature, it is called purwakanthi guru swara. This sentence acts as a closing sentence and conclusion to the content of the appeal. This means, by implementing WFH, the risk of virus transmission can be reduced, but at the same time, citizens can still be productive although from home.

At the textual level, this poster (Figure 3) is classified as persuasive discourse. Most of the sentences are constructed through the selection of directive diction which has persuasive nuances. Meanwhile, in the language aspect, the poster in Figure 3 uses two levels of language. Sentences 1 and 4 use krama language, which shows politeness, while other sentences use ngoko, which brings familiar and closeness nuances.

On both posters (Figure 2 and 3 ), there are several markers of modality. The modality is an element used by speakers to express an attitude to speech partners, for example, informing, ordering, prohibiting, and asking (Sutedi in Afyolanda, Widjajanti, \& Husniah, 2018). On those posters, there exist markers of deontic modality and markers of the intentional modality that can be seen in Tabel 1 .

Table 1 The Table of Modality

\begin{tabular}{ll}
\hline \multicolumn{1}{c}{ Intentional Modality } & \multicolumn{1}{c}{ Deontic Modality } \\
\hline $\begin{array}{l}\text { Monggo sesarengan bantu } \\
\text { pemerintah }\end{array}$ & \\
Ayo kerjo soko omah wae & Ojo nganti ketularan Corona \\
Monggo poro sederek & Ojo cedhak-cedhak \\
wargo kutha Solo & \\
Ayo bantu pemerintah \\
Surakarta \\
\hline
\end{tabular}

Based on Table 1, three deontic modalities and four intentional modalities are found. The word ojo (do not) is classified as a deontic modality of the prohibition marker. This deontic modality has the function of stating a prohibition to readers (Afyolanda, Widjajanti, \& Husniah, 2018). Meanwhile, the words ayo (let's) and monggo (let's)are classified as an intentional modality of the invitation markers. The invitation modality marker serves to invite readers or express the speaker's or text producer's attitude when actualizing an event with a speech partner or reader (Afyolanda, Widjajanti, \& Husniah, 2018).

From the textual dimension perspective, those posters have been constructed in the Javanese language with the form of imperative, declarative sentences, and have a thick persuasive nuance. Also, there are two modalities, namely the deontic modality of prohibition and the intentional modality of invitation. From these findings, it can be concluded that those posters are intended to influence and persuade the community in the middle of the COVID-19 arena. This effort is also supported by the 'power' modal of the Mayor of Surakarta's institution as a power-holders and stakeholders institution.

Based on Eriyanto in Lubis (2020), in the textual dimension, there are three elements, namely representations, identities, and relations. From those posters, it can be found identity, representation, and relation. On those posters are found the producer and consumer identities. The identity of the discourse producer is F. X. Hadi Rudyatmo (the Mayor of Surakarta 2016-2020) as the leader who has the authority to regulate the city of Surakarta. The identity of the discourse consumers is the people of Surakarta, which is reflected with the clause "wargo kutha Solo' and as the main target of those posters. Language is not only a system of sound, morphology, and syntax, but language also carries cultural identity (Santoso, 2006). Based on this, the use of the Javanese language also indicates a pattern of Javanese cultural identity.

Those posters represent power and culture. This is reflected in the identity of the producer of the text as a powerholder and the consumer of the text as that interconnected in the communication of Javanese language and culture. Based on these representations, it is found two aspects of the relation; namely, power relations and cultural relations.

In the power relation, Fairclough in Fatmawati and Cahyono (2018) has stated that discourses in the scope of power are related to the control exercised by a powerful participant on a non-powerful participant. The Mayor of Surakarta's institution acts as a powerful participant, while the citizens act as a non-powerful participant. The citizen here becomes some kind of 'influenced subject' from the persuasive effort on those posters. In cultural relations, the two participants also relate in the corridors of Javanese culture identity. In the textual dimension, this cultural relation is reflected in the use of Javanese language (ngoko and krama) grammar as the basis for textual construction. It also indicates politeness communication and the cultural closeness from the Mayor of Surakarta towards the citizen.

The discussion of dimensions in the two COVID-19 posters continues on the dimension of discourse practice. The discourse practice dimension focuses on how a text producer processes an existing discourse (Eriyanto in Lubis, 2020). Based on Fairclough's three-dimensional framework, 
discourse practice dimensions discuss the production, distribution, and consumption processes (Fairclough in Dabir-Moghadam \& Raeesi, 2019).

The production process is closely related to the text producer (Saraswati \& Sartini, 2017). Those posters are produced by the Mayor of Surakarta along with his staff or can be called the Mayor of Surakarta's institution. As an official city government, the institution has a legal basis or references to the central government policy when producing those posters.

In the production process, those posters are intertextually related to two different central government regulations. The production process of the first poster has intertextuality with the Minister of Health's regulation No. HK.01.07/MENKES/382/2020 about health protocols for the public in the context of preventing and controlling COVID-19 (Indonesian Ministry of Health, 2020). Because poster in Figure 2 has some information referring to the health protocol, such as an appeal to wear a protective tool (e.g., mask \& glove), wash hands, and social distancing.

The second poster contains a persuasive invitation to the Surakarta community to support the Surakarta city government policy to implement the WFH program. This poster (Figure 3) has intertextuality based on the KEPPRES (presidential decree) Number 11 the Year 2020 concerning the determination of COVID-19 as a type of disease that causes a public health emergency. Then by considering UU Nomor 6 Tahun 2018, which requires Indonesia to implement a health quarantine process as a protective effort to prevent the exit or entry of a disease (Widiastuti, Ismail, \& Iswanto, 2020). The emergency condition caused by COVID-19 forced the Surakarta city government and the Mayor of Surakarta to implement the WFH program.

From this intertextuality, it can be concluded that the production of those posters is not arbitrary or just making up. Those posters have an intertextual reference to the central government regulations. This automatically also creates 'authority weight' and adds the persuasion value of those posters. In the production process, those posters are produced in the Javanese language. The choice of regional (Javanese) language indicates cultural relations between producers and consumers (Burhanudin, Sumarlam, \& Rakhmawati, 2021). The use of the Javanese language shows that the Mayor of Surakarta wants to form a cultural relationship with the people of Surakarta. Those posters are produced in the local language intended to make the message easy to receive by Surakarta's social minds. This is related to Imai, Kanero, and Masuda's (2016) research that language closely relates to culture, psychology, and human cognition.

The next process is the distribution process. Those two posters are distributed via social media, Instagram. Social media (e.g., Instagram) makes a discourse would reach the public faster (Burhanudin, Sumarlam, \& Rakhmawati, 2021). Social media such as Instagram also eliminates the distribution limits. That virtual social network allows people in different areas to access those posters instantly anytime and anywhere. However, to access those posters, someone must meet requirements, access knowledge, internet network, software, and hardware.

The distribution process through social media is related to the e-government service model. E-government takes advantage of modern information technology to present information and services efficiently in a minimal time and cost (Mahmoodi \& Nojedeh, 2016).

The distribution process of those posters is closely related to the consumption process. Those posters are intended to be consumed by the citizens of Surakarta. This is shown by two things; first, the text is produced directly by the Mayor of Surakarta's institution and then distributed through the Instagram account of the Mayor of Surakarta (@fx.rudyatmo). Second, there is the phrase 'wargo kutha Solo'. The word ' wargo' refers to the member of an administrative area, and the word 'Kutha Solo' refers to Surakarta city. These two things show that those posters are intended to be consumed by Surakarta's citizens.

However, because those posters are distributed via social media (Instagram), the consumer boundaries are gone. This means those posters can be consumed by any consumer from anywhere, as long have access capabilities (e.g., access knowledge, internet network, software, and hardware). In addition, with the advancement of translate engines such as Google Translate, language barriers (including Javanese translation) can be resolved (Burhanudin, Sumarlam, \& Rakhmawati, 2021).

Distribution through social media also indicates a direct approach between producers and consumers. Unlike other mass media (newspapers, tv, magazines), which have an editing and editorial process, social media allows information from producers to be released directly to the consumers without any intervention from the media. Based on Chen et al. (2020), the use of social media to spread the information by the government can positively affect community involvement and role during the COVID-19 pandemic. This means that those posters are a direct effort by the mayor institution to affect citizen participation in dealing with the COVID-19.

From the production process, there are indications that the Mayor of Surakarta's Institution, through its authority and power, produces the poster in such a way to influence the citizens. The text in the posters is produced as a persuasive discourse that has the power to change behavior or shape behavior. This is related to the production of a text that utilizes the intentional modality of the invitation, such as monggo, ayo, and the deontic modality of prohibition, such as the word ojo. Both modalities are classified as highlevel modalities, based on Martin in Khaofia (2018), that the dominant party will tend to use a high-level modality while the type of modulation used is an obligation. From that notion, the Mayor of Surakarta's institution as the dominant party determines several obligations for certain behaviors that must be obeyed 
by the citizen. The obligation is also strengthened by the intertextuality of central government regulations on those posters.

Analysis continues to the sociocultural dimension. The sociocultural dimension is related to the contexts outside the text that affects the production of a discourse (Eriyanto in Lubis, 2020). This sociocultural dimension is divided into three levels. Those three levels are situational, institutional, and social levels (Fairclough, 2010). First, the situational level is a condition, state, or specific atmosphere that underlies the emergence of a discourse (Sukma, Mayasari, \& Hariyanto, 2019). The COVID-19 pandemic is the situation that underlies the emergence of those posters. Since the first quarter of 2020, Central Java province and Surakarta city have been affected by the COVID-19. In Central Java, the first COVID-19 case was reported in Surakarta in March 2020 (Nidaa, 2020). Responding to that pandemic situation, the Mayor of Surakarta's institution took various actions, one of which is the efforts to persuade and educate the citizen through those posters. On the situational level, those posters are a manifestation of response from the Mayor of Surakarta's institution to the pandemic situation. Then through those posters, appeals and educative information are delivered to the public to create public awareness and discipline towards health protocols and government policies for dealing with the COVID-19 pandemic.

The second level is the institutional level. This level discusses the influence of institutions or organizations on the process of a discourse (Kartikasari, 2020). When viewed from the institutional level, those posters are produced by the Mayor of Surakarta's institution. As an official institution, the Mayor of Surakarta institution certainly has a 'power' capital. According to Fairclough in Ye, Cheng, \& Zhao (2019), institutions are closely related to 'power", and through discourse, powerful actors control and limit nonpowerful participants. This means that through the production of those posters, the Mayor of Surakarta's institutions (powerful participants) try to control and limit Surakarta's citizen's (non-powerful participants) activities and behavior by adjusting health and quarantine protocol regulations.

According to Vidiadari (2017), The discourse that is formed by power relations will be closely related to the practice of hegemony. In the institutional context, the production of those posters is influenced by the power relation and ideology of the ruling institution. However, it is not intended as an instrument of power interest or political struggle, but rather as a practice of social influencing and protective measures as a form of leaders who try to save social safety amid the COVID-19 pandemic.

The third level is the social level related to the macro context, such as the political system, the economic system, and the cultural system of society (Kartikasari, 2020). In those posters, the most prominent social level is the cultural context and social conditions context.
In the cultural context, as found in those posters, there is a very strong Javanese cultural context. This is reflected in the use of Javanese and the use of ngoko and krama language levels, which brings the politeness and closeness nuances in the cultural context. This cultural context is also strengthened by the caricature of F. X. Hadi Rudyatmo, who is depicted wearing traditional Javanese clothing that can be seen in Figure 4.

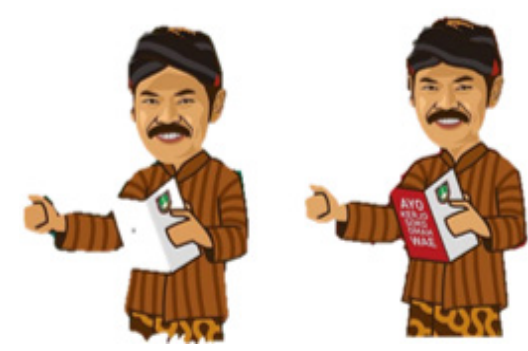

Figure 4 Caricature of F. X Hadi Rudyatmo, Surakarta's Mayor (2016-2021)

Figure 4 shows a caricature of F. X Hadi Rudyatmo (Mayor of Surakarta 2016-2021) depicted wearing batik lurik or surjan and blangkon (head cover). Surjan and blangkon are essentially traditional Javanese clothes, especially in Central Java (Iskandari $\&$ Widharto, 2019). Based on the caricature and the use of Javanese language in those posters, it indicates that the Mayor of Surakarta is trying to forge a close cultural relationship with Surakarta's people. By building these cultural relations, those posters may attract more attention, and the message will easily be accepted by Surakarta's people. After all, any discourse process or language between speakers and listeners, writers, and speakers is correlated with a certain cultural environment (Keating \& Duranti, 2011).

The cultural context on those posters is also related to the condition of Surakarta's ethnicity, which is dominated by the Javanese ethnic. This is also associated with Surakarta as one of the centers of Javanese culture, which is known as 'The Spirit of Java' (Burhanudin, Sumarlam, \& Rakhmawati, 2021). This cultural context significantly influenced the production process and emergence of those posters. Bilá and Ivanova (2020) have stated that in the relationship between humans, language, and culture, humans are defined as biological, social, and cultural beings. All these aspects are closely tied to the inseparable unity.

There is one more context related to the existence of those posters, namely social conditions. Fairclough in Palupi (2018: 379) states that discourse is integrated with social conditions. The social conditions that led to the emergence of those posters were the social conditions of Surakarta's citizens, which had worsened due to the COVID-19 pandemic. To answer the social conditions, the Mayor of Surakarta's Institution has taken various actions, one of which is persuasive- 
educative action represented by those posters.

Those posters have become a medium for The Mayor of Surakarta's institution to influence social behavior towards a more adaptive social condition to the COVID-19 pandemic situation. The use of posters to spread influence has to do with the poster's ability to attract attention. Research on poster discourse conducted by Wibisono and Hartanto (2019) has stated that posters have high enough dramatic power to captivate and attract readers' attention.

These three dimensions (textual, discourse, and sociocultural) are united in the persuasive-educational posters used by the Mayor of Surakarta's institution to respond to the COVID-19 pandemic conditions in Surakarta. In line with this, Fairclough in Mahmudi et al. (2020) argues that when discourse is understood as an action, discourse becomes the realization of an effort to respond to certain situations or social contexts.

Based on research by Mahmudi et al. (2020), text or discourse is produced in unique conditions or atmospheres because of the uniqueness of these situations and conditions; one text will be different from other texts. In the context of these unique conditions, Finset et al. (2020) have said that the COVID-19 pandemic is referred to as a unique condition or situation (which has never happened before) that asks political authorities to act along with the health system. It shows that those COVID-19 posters have dialectical ties to the COVID-19 situation. If the COVID-19 situation had never occurred, those posters would never have been produced and even exist.

When viewed as a social construction, discourse is created and perpetuated by those with the power and communication tools (Ye, Cheng, \& Zhao, 2019). In line with this, the poster is made by the Mayor of Surakarta as the holder of power and stakeholders. The position has the 'power' to have an impact on the influence and the force aspect of those posters. Moreover, mass communication is easy to reach and instantaneous in this era, making it easy to spread influence through discourse. There is no need to use conventional mass media (i.e., tv, newspapers, radio), just smartphones or computers, and social media; the government can directly distribute and perpetuate persuasive-educative discourse to create people awareness COVID-19 pandemic. Based on research by Kumar, Gupta, and Srivastava (2020), it is stated that the internet (social media) is a good medium for creating awareness, alerting, and exercising social control in the fight against COVID-19.

Based on Kartikasari's research (2020), critical discourse, especially Norman Fairclough's CDA framework, emphasizes discourse as a form of interaction. Through critical discourse analysis, it appears that the use of spoken and written language is a form of social practice. In line with this, those posters are a form of interaction and social practices that occur between power-holders and the community. The social interaction in those posters is the realization of the protective measure by the government to deal with the COVID-19 pandemic. Because protective measures need to be done by the authorities to maintain social safety amid pandemic conditions like this. Because of that, those poster is also related to the 'flattening the curve' strategy, as shown in the Williams \& CañónMontañez (2020) research that can be seen in Figure 5.

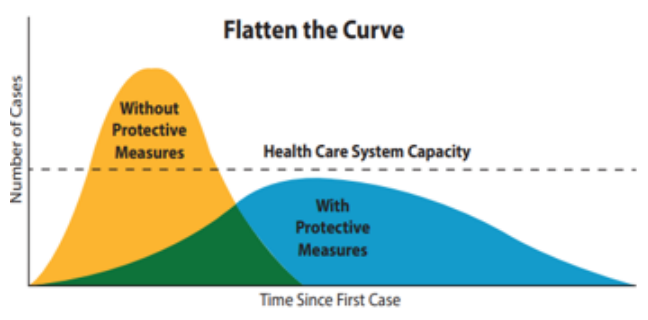

Figure 5 Flatten the Curve Strategy (Williams \& Cañón-Montañez, 2020)

Based on Figure 5, striving for a protective measure strategy (WFH, wearing masks, social distancing, washing hands) can reduce the rate of infection cases and flatten the COVID-19 curve to avoid overloading the health system (Williams \& Cañón-Montañez, 2020). In this regard, those COVID-19 posters are a form of an effort from the Mayor of Surakarta's institution to encourage, persuade, and educate the citizen to apply protective measures (WFH, wearing masks, social distancing, washing hands). These efforts will create the 'flatten of the curve' effect, so the spread of the virus and handling of the COVID-19 case in Surakarta can be controlled.

Those Javanese COVID-19 posters can also act as an instrument to stimulate social change. According to Pietikäinen (2016), there is a complex relationship between language, power, and social change. In line with this, according to the research of Van Bavel, Baicker, and Willer (2020), fundamental social change is needed in dealing with a global scale pandemic like this (COVID-19). These social changes refer to a more adaptive and relevant social order to adjust the COVID-19 pandemic, known as the 'new normal' order.

According to Wahyuningsih (2020), various government policies to overcome the COVID-19 pandemic have direct implications for all forms of social change in society, which can then result in a 'new normal' condition. One of the efforts to create social change is through persuasion policies such as those posters. However, these persuasion efforts are also supported by repression efforts. Based on the Chief of Police's edict number MAK/2/III/2020 about the obedience to government policies in handling the spread of the coronavirus, law enforcement institutions will take firm action against anyone who does not obey the government appeals and policies amid the COVID-19 pandemic (Fauzi, Satyawan, \& Nurhaeni, 2020). This means that the government's persuasive efforts, such as those posters, are supported by firm repressive action from law enforcement institutions. 
At the end of the discussion regarding the three-dimensional findings, it shows those posters are used by the Mayor of Surakarta's institution to influence and organize the people of Surakarta to act for the common good amid the COVID-19 pandemic. Persuasion discourse such as the poster can stimulate social change towards new normal order. Based on research by Martinloi, Tangkudung, and Harilama (2020), persuasion efforts are one of the ways or innovations in the process of creating social change amid the COVID-19 pandemic.

\section{CONCLUSIONS}

Based on the result and discussion, it can be concluded that the mayor of Surakarta's Javanese COVID-19 posters has three dimensions. The first dimension is the text dimension. The textual dimension is a micro-structural dimension that discusses linguistic elements in discourse. In the textual dimension, those posters are compiled using imperative and declarative sentences, and also found the use of markers of deontic and intentional modalities. The form of the sentence and the modalities convey a strong persuasive impression. Besides, there are also identities and representations of the producers as powerful participants and consumers as non-powerful participants that connect in the corridor of Javanese cultural and power relations.

The second is the discursive practice dimension. This dimension is related to the production, distribution, and consumption process. The production process on those posters is closely related to the Mayor of Surakarta's institution as the producer of those posters. The Mayor of Surakarta's institution also acts as the power holder that responsible for regulating the Surakarta society during a pandemic. In the production process, the Mayor of Surakarta's institution refers to central government regulations. Those posters are distributed through the social media Instagram, which made the posters spread quickly in the community with minimal costs. Also, the distribution process has been done directly by text producers through Instagram. The consumption of text is related to the consumer of text, namely the people of Surakarta, who target those posters. Because the distribution process has been done through social media, it also eliminates the limits of consumers and consumption.

The third is the socio-cultural dimension. This macrostructural dimension relates to the context outside the text. In this dimension, three levels are found: the situational, institutional, and social levels. At the situational level, it is found that the poster is influenced by the COVID-19 pandemic situation as a unique and distinctive situation. At the institutional level, it is found that The Mayor of Surakarta's institution is very influential in the production process of those posters. Meanwhile, the social level on those posters is related to the cultural and social condition context. In the cultural context, those posters are influenced by the Javanese cultural context. In the social condition context, those posters are influenced by the social conditions of the people of Surakarta, which have been hit by the COVID-19 pandemic since March 2020.

Based on the result, the research found that those posters are functioned by the Mayor of Surakarta's Institution as a protective measure to influence, educate, and regulate the citizens amid the COVID-19 pandemic. Also, those posters can stimulate social change towards a more adaptive and appropriate social life amid the COVID-19 situation, namely the new normal order. The research proposes a finding which is different from previous CDA studies. It finds that regional language can be used by the authorities to produce socio-cultural relations in an effort to persuade or influence society with a relevant cultural ecosystem to stimulate a social change.

The implication of the research is to increase the reader's critical level in understanding a discourse, especially persuasive discourse or posters amid this information era. Also, the research can be a reference for further research, especially research related to critical analysis discourse.

The research has several limitations; first, the data have a very limited and scarce amount. Researchers have observed on the internet, site, or social media, especially on the Mayor of Surakarta. Surprisingly the Mayor of Surakarta (2016-2021), until the end of office in February 2021, only released two fully Javanese posters. Both posters are related to COVID-19. From a certain perspective, this can also be seen as uniqueness. Second, the research is only limited to discussing the three-dimension elements using Fairclough's CDA and only limited to posters of the Mayor of Surakarta (2016-2021). Based on this, the research suggests that the next research does a more macro context or even more in-depth study on the same discourse subject. Also, the research recommends the future research considers topics that can provide richer data.

\section{REFERENCES}

Adiantika, H. N. (2020). Contrastive analysis between Indonesian and English declarative sentences. ELT in Focus, 3(1), 15-25. https://doi.org/10.35706/ eltinfc.v3i1.3695.

Afyolanda., Widjajanti, A., \& Husniah, F. (2018). Modalitas kalimat pada antologi cerita pendek lukisan kaligrafi karya A. Mustofa Bisri. RETORIKA: Jurnal Bahasa, Sastra, dan Pengajarannya, 11(2), 140-153. https:// doi.org/10.26858/retorika.v11i2.6211.

Azizan, M., Ismail, H. H., \& Qaiwer, S. N. (2020). Power and solidarity in positive Facebook postings amidst Covid-19 in Malaysia. Journal of Nusantara Studies (JONUS), 5(2), 329-364. https://doi.org/10.24200/ jonus.vol5iss2pp329-364.

Bechler, C. J., \& Tormala, Z. L. (2020). Misdirecting persuasive efforts during the COVID-19 pandemic: 
The targets people choose may not be the most likely to change. Journal of the Association for Consumer Research, 6(1), 1285-1297. https://doi. org/10.1086/711732.

Bilá, M., \& Ivanova, S. V. (2020). Language, culture, and ideology in discursive practices. Russian Journal of Linguistics, 24(2), 219-252. https://doi. org/10.22363/2687-0088-2020-24-2-219-252.

Burhanudin, H., Sumarlam., \& Rakhmawati, A. (2021). Dimensionalitas imbauan work from home dalam akun Instagram Wali Kota Surakarta 2016-2021 F. X. Hadi Rudyatmo: Analisis wacana kritis Norman Fairclough. Seminar Internasional Riksa Bahasa, 14, 145-153.

Chen, Q., Min, C., Zhang, W., Wang, G., Ma, X., \& Evans, R. (2020). Unpacking the black box: How to promote citizen engagement through government social media during the COVID-19 crisis. Computers in Human Behavior, 110, 106380. https://doi. org/10.1016/j.chb.2020.106380.

Dabir-Moghadam, M., \& Raeesi, H. (2019). A critical discourse analysis of Iranian sport media: A case study. International Journal of Applied Linguistics and English Literature, 8(3), 84-92. https://doi. org/10.7575/aiac.ijalel.v.8n.3p.84.

Damayamti, D. T., \& Masitoh, A. (2020). Strategi koping siswa dalam menghadapi stres akademik di era pandemi Covid-19. Academica: Journal of Multidisciplinary Studies, 4(2), 185-198.

Fairclough, N. (2010). Critical discourse analysis: The critical study of language. United Kingdom: Taylor \& Francis.

Fatmawati, Z. R., \& Cahyono, S. P. (2018). Power of Sakdiyah Ma'Ruf in stand-up comedy through appraisal approach. ETERNAL (English Teaching Journal), 9(2), 1-15. https://doi.org/10.26877/ eternal.v9i2.2965.

Fauci A. S., Lane, H. C., Redfield, R. R. (2020). Covid-19 navigating the uncharted. The New England Journal of Medicine, 382, 1268-1269. https://doi. org/10.1056/NEJMe2002387.

Fauzi, A., Satyawan, I. A., \& Nurhaeni, I. D. A. (2020). Social marketing communication strategy on "Covid-19 Alert Village" of Central Java regional police: Case study on Covid 19 alert village at Panggung Lor, North Semarang. Proceeding of the $6^{\text {th }}$ International Conference on Social and Polical Science (ICOSAPS 2020), pp 139-146. https://doi. org/10.2991/assehr.k.201219.021.

Finset, A., Bosworth, H., Butow, P., Gulbrandsen, P., Hulsman, R. L., Pieterse, A. H., Street, R., Tschoetschel, R., \& Van Weert, J. (2020). Effective health communication - A key factor in fighting the COVID-19 pandemic. Patient Education and Counseling, 103(5), 873-876. https://doi. org/10.1016/j.pec.2020.03.027.

Imai, M., Kanero, J., \& Masuda, T. (2016). The relation between language, culture, and thought. Current Opinion in Psychology, 8, 70-77. https://doi. org/10.1016/j.copsyc.2015.10.011.

Indonesian Ministry of Health. (2020). Keputusan kesehatan nomor: HK.01.07/MENKES/382/2020 tentang protokol kesehatan bagi masyarakat di tempat dan fasilitas umum. Jakarta: Sekretariat Negara.

Iskandari, D., \& Widharto, Y. (2019). Peningkatan kualitas hidup pengrajin dan pengguna blangkon (gaya Yogyakarta) melalui pendekatan anthropometri serta penerapan sistem produksi yang sesuai (paper review). Industrial Engineering Online Journal, $8(3), 1-6$.

Kartikasari, S. (2020). Analisis wacana kritis Nourman Fairclough terhadap pemberitaan Jokowi naikkan iuran BPJS di tengah pandemi. An-Nida: Jurnal Komunikasi Islam, 12(2), 113-124. https://doi. org/10.34001/an.v12i2.1608.

Keating, E., \& Duranti, A. (2011). Discourse and culture. In T. A. Van Dijk (Ed.), Discourse Studies: A Multidisciplinary Introduction, pp. 331-353. California: Sage Publication, Ltd.

Khaofia, S. (2018). Modalitas sebagai realisasi makna interpersonal pada talkshow Mata Najwa on Stage "Semua Karena Ahok". Prasasti: Journal of Linguistics, 3(2), 222-234. https://doi.org/10.20961/ prasasti.v3i2.12490.

Kumar, A., Gupta, P. K., \& Srivastava, A. (2020). A review of modern technologies for tackling COVID-19 pandemic. Diabetes \& Metabolic Syndrome: Clinical Research \& Reviews, 14(4), 569-573. https://doi. org/10.1016/j.dsx.2020.05.008.

Mahmoodi, R. K., \& Nojedeh, S. H. (2016). Investigating the effectiveness of e-government establishment in government organizations. Procedia - Social and Behavioral Sciences, 230, 136-141. https://doi. org/10.1016/j.sbspro.2016.09.017.

Mahmudi, M., Amrullah, H. F., Iskandar, D., Ramadhanti, N., Hasibuan, M., \& Widyastuti. (2020). Commodification of Dieng gimbal hair children in digital media: Norman Fairclough's critical discourse analysis. E-Bangi, 17(9), 168-181.

Martinloi, M., Tangkudung, J. P. M., \& Harilama, S. H. (2020). Pola komunikasi sosial di masyarakat pada masa pandemi Covid-19 di kelurahan Teling Atas, kecamatan Wanea. Acta Diurna Komunikasi, 3(1), $1-8$.

Mo, P., Xing, Y., Xiao, Y., Deng, L., Zhao, Q., Wang, H., Xiong, Y., Cheng, Z., Gao, S., Liang, K., Lou, M., Cheng, T., Song, S., Ma, Z., Chen, X., Zheng, R., Cao, Q., Wang, F., \& Zhang, Y. (2020). Clinical characteristics of refractory COVID-19 pneumonia in Wuhan, China. Clinical Infectious Diseases, 270, 1-6. https://doi.org/10.1093/cid/ciaa270.

Lubis, N. (2020). Cadar dalam ruang publik: Analisis wacana kritis Norman Fairclough pada Instagram @ aisyiyahpusat. Tazkir: Jurnal Penelitian Ilmu-ilmu Sosial dan Keislaman, 6(2), 209-224. https://doi. org/10.24952/tazkir.v6i2.2132.

Nidaa, I. (2020). Gambaran pengetahuan masyarakat Pekalongan tentang Covid-19. Jurnal Litbang Kota Pekalongan, 19, 64-73.

Olivia, S., Gibson, J., \& Nasrudin, R. (2020). Indonesia in the time of Covid-19. Bulletin of Indonesian Economic Studies, 56(2), 143-174. https://doi.org/1 
0.1080/00074918.2020.1798581.

Radi, G., Diotallevi, F., Campanati, A., \& Offidani, A. (2020). Global coronavirus pandemic (2019-nCOV): Implication for an Italian medium size dermatological clinic of a II level hospital. Journal of the European Academy of Dermatology and Venereology, 34(5), 213-214. https://doi.org/10.1111/jdv.16386.

Rudyatmo, H. F. X. (2020, March 28). Ojo dolan kluyuran, mengko ketularan. Retrieved on August $16^{\text {th }}, 2020$ from https://www.instagram.com/p/BRevPOhVL9/.

Rudyatmo, H. F. X. (2020, April 2). Wong Sabar Rejekine Jembar. Retrieved on August 16 ${ }^{\text {th }}, 2020$ from https:// www.instagram.com/p/B-d8JLIBLIq/.

Palupi, D. D. (2018). Critical discourse analysis of the meme makasih yang lebih cantik. In Proceedings of the International Conference on Language Phenomena in Multimodal Communication (KLUA 2018), pp. 378-383. https://doi.org/10.2991/klua-18.2018.57.

Pietikäinen, S. (2016). 12 critical debates: Discourse, boundaries and social change. In N. Coupland (Ed.), Sociolinguistics: Theoretical debates, pp. 263-281. https://doi.org/10.1017/CBO9781107449787.013.

Santoso, B. (2006). Bahasa dan identitas budaya. Sabda: Jurnal Kajian Kebudayaan, 1(1), 44-49. https://doi. org/10.14710/sabda.1.1.44-49.

Saraswati, A., \& Sartini. (2017). Wacana perlawanan Persebaya 1927 terhadap PSSI: Analisis wacana kritis Norman Fairclough. Mozaik Humaniora, 17(2), 181-191. https://doi.org/10.20473/mozaik. v17i2.8511.

Sukma, A. D., Mayasari., \& Hariyanto, F. (2019). Analisis wacana kritis pernyataan mantan ketua umum PSSI dan gubernur Sumatera Utara "Kalau Wartawan Nya Baik Nanti Timnas Nya Baik" dalam tayangan Youtube Kompas TV. Jurnal Linguistik Terapan, 9(2), 20-30.

Sultan, S., \& Rapi, M. (2020). Positive discourse analysis of the Indonesian government spokesperson's discursive strategies during the Covid-19 pandemic. GEMA Online Journal of Language Studies, 20(4), 251-272. https://doi.org/10.17576/gema-20202004-14.

Sumarlam, S. (2016). Representasi kekuasaan melalui sabda raja pada teks berita mengenai konflik internal keraton Yogyakarta (Sebuah analisis wacana kritis). Prosiding Prasasti, O(0), 58-70. https://doi. org/10.20961/pras.v0i0.1444.
Suprayitno, D. (2020). Konstruksi wacana citra kepemimpinan Joko Widodo dalam penanganan Covid-19 pada infografis CNBC Indonesia. Jurnal Ilmu Komunikasi Acta Diurna, 16(2), 28-49. https:// doi.org/10.20884/1.actadiurna.2020.12.2.3265.

Tiruneh, D., Baye, G., \& Dubi, Y. B. (2020). A critical discourse analysis of COVID-19 in Ethiopia: Rethinking the past and defining the present. Journal of Language and Literature, 20(2), 318-331. https:// doi.org/10.24071/joll.v20i2.2608.

Van Bavel, J. J., Baicker, K., \& Willer, R. (2020). Using social and behavioural science to support COVID-19 pandemic response. Nature Human Behaviour, 4(5), 460-471. https://doi.org/10.1038/s41562-0200884-z.

Vidiadari, I. S. (2017). Relasi gender dalam kolom humor "Si Palui" di Banjarmasin Post (Analisis wacana kritis Norman Fairclough pada kolom humor $\mathrm{Si}$ Palui di Banjarmasin Post). ARISTO, 5(2), 259-290. http://dx.doi.org/10.31227/osf.io/25tse.

Wahyuningsih, C. D. (2020). Kenormalan baru dan perubahan sosial dalam perspektif sosilogi. Mimbar Administrasi FISIP UNTAG Semarang, 1(21), 104122.

Wibisono, T., \& Hartanto, W. (2019). Analisis wacana kritis pada poster SMA Al Hikmah full day Surabaya sebagai motivasi pembelajaran milenial 4.0. Prosiding Seminar Nasional PBSI UPY 2019, 1(1), 140-146.

Widiastuti, A., Ismail, M. R., \& Iswanto, A. Z. (2020). Analisis semiotika meme 'Profesi Yang Tidak Dapat Work From Home' selama pandemi Covid-19. Semiotika: Jurnal Komunikasi, 14(1), 1-7. http:// dx.doi.org/10.30813/s:jk.v14i1.2193.g1774.

Williams, G., \& Cañón-Montañez, W. (2020). COVID-19: Lo que hemos aprendido hasta ahora. Revista Cuidarte, 11(2), 1-4. https://doi.org/10.15649/ cuidarte. 1225 .

Ye, N., Cheng, L., \& Zhao, Y. (2019). Identity construction of suspects in telecom and internet fraud discourse: From a sociosemiotic perspective. Social Semiotics, 29(3), 319-335. https://doi.org/10.1080/10350330.2 019.1587847.

Yuvaraj, M. (2020). Global responses of health science librarians to the COVID-19 (Corona virus) pandemic: A desktop analysis. Health Information \& Libraries Journal, 37(4), e12321. https://doi. org/10.1111/hir.12321. 